Article

\title{
Can CEO's Humble Leadership Behavior Really Improve Enterprise Performance and Sustainability? A Case Study of Chinese Start-Up Companies
}

\author{
Qiuzhen Ren ${ }^{1} \mathbb{D}$, Yingjie $\mathrm{Xu}^{2, *}$, Ranran Zhou ${ }^{3}$ and Jingdong Liu ${ }^{4}$ \\ 1 Department of Economics and Management, Northeast Forestry University, Harbin 150040, China; \\ renqiuzhen@nefu.edu.cn \\ 2 Trinity Business School, Trinity College Dublin, Dublin 2 D02 PN40, Ireland \\ 3 School of Economics and Management, Harbin Engineering University, Harbin 150001, China; \\ zhouran@hrbeu.edu.cn \\ 4 School of Business, Anhui University, Hefei 230039, China; ljdahu@ahu.edu.cn \\ * Correspondence: xuy2@tcd.ie
}

Received: 28 February 2020; Accepted: 9 April 2020; Published: 14 April 2020

check for updates

\begin{abstract}
The relationship between the leadership behavior of a chief executive officer (CEO) and start-up enterprise performance is key to effecting the survival and development of start-ups in the era of the internet economy. Currently, most studies on this topic focus more on the role of leadership effectiveness but rarely explore the CEO's humility in leadership and the mechanism of its behavior affecting enterprise performance and its sustainable development. Based on leadership theory and upper-echelon theory, we build a research model of CEO's humble leadership behavior, top management team's (TMT's) transactive memory system, and start-up enterprise performance, as well as the moderating roles exerted by strategic flexibility. Further, to validate the hypothesis, 400 valid questionnaires are obtained. Based on those data, the empirical results show humility, as a virtue, not only can significantly and positively improve start-up firm performance but also can promote the firm's sustainable development in the long run by providing a trustworthiness climate for TMT members. Moreover, TMT's transactive memory systems play a partial mediating role in the relationship between CEO's humble leadership behavior and start-up enterprise performance. Meanwhile, strategic flexibility significantly and positively moderates the relationship between CEO's humble leadership behavior and startup entrepreneurial performance. Finally, the theoretical and practical implications are discussed, and directions for future research are proposed.
\end{abstract}

Keywords: CEO's humble leadership behavior; TMT's transactive memory system; strategic flexibility; start-up enterprise performance

\section{Introduction}

\subsection{The Effect of CEO Humility on Start-Up Performance}

With the development of the global internet economy and a rapidly changing business environment, sustainable development in enterprise has been of great interest among corporate leaders. As the largest developing country, China's market economy shows a trend towards diversified development. Start-up enterprises with the characteristic of newness and smallness are the main components of China's sustainable economic development. However, under the complex and volatile business environment, start-up corporation are facing huge risks and challenges in the process of innovation and sustainable development [1]. Therefore, the top leader becomes the core of enterprise development for the start-up enterprise as her/his strategic decision-making directly affects the start-up's development 
and profitability. In management practice, the leadership behavior of chief executive officers (CEOs) plays a decisive role for enterprises in achieving a high performance and development since they generally handle the daily affairs of an enterprise on behalf of the board of directors. Recent studies have manifested that not only CEO's demographic characteristics including gender, age, and education background but also the CEO's psychological traits such as overconfident personality, humility, and optimism have direct or indirect effects on decision-making, which would further influence the firm's sustainable performance [2-4]. Furthermore, humility is considered as the one of virtues that effectively facilitate the transition to a more sustainable economic mode to face complex environmental and social challenges [5]. In the case of a start-up, it is possible that a humble CEO could not only promote the firm's financial performance in the short run but also facilitate the firm's sustainable development performance in the long run.

With the development of leadership theory, humble leadership has been gradually established as a new "bottom-up" leadership style. Generally, humble leadership is conceptually associated with moral, ethical, participative, empowering, and servant leadership [6,7]. Compared with other psychological attributes, humility helps drop airs of omniscience and authority, learn along with others, and open to self-improvement, which provides the lever to sustainable development for firms [8]. With those characteristics, CEO humility can empower and integrate top management team (TMT), foster the firm's employee's innovation as well as enhance firm performance. Currently, most studies on CEO humility and firm performance mainly focus on established firms [9]; however, the studies on start-up firms are rare but still attractive. Research by Peterson found that the relationships between CEO personality and organizational characteristics were stronger in start-up firms and in dynamic environments when compared to larger, more static environments [10]. In addition, the success of start-up firms is more uncertain and challenging than that of more established firms [11,12]. Importantly, Kantbutra suggested that a firm where staff can effectively engage in firm activities can increase its long-term sustainability [13]. Therefore, it is particularly important to explore how CEO's humble leadership behavior affects performance of start-ups.

\subsection{The Existence of Influencing Mechanism}

CEO leadership behavior is considered as an important ingredient for the revitalization of organizations and as critically important to the top management of organizations [14]. Generally, there are three main streams of research looking at the effect of a CEO on firm performance, namely (i) the effects of CEO individual factors on firm performance [15]; (ii) how the CEO affects firm performance by influencing top management team's (TMT) process [16,17]; (iii) examine the moderating effect on those relationships [18]. It is vital to investigate the inevitable mediators appearing to account for different stages (e.g., TMT processes and environmental complexity) in the effect of CEO attributes on firm performance. However, there are less studies systematically integrating these mediators that exist in the different stages into a model and probing their effect on the relationship between CEO humility and start-up performance.

\subsubsection{The Role of Transactive Memory System}

TMT is a knowledge-based team that emphasizes diversification and functional division of members [19]. The diversification of TMT member can improve firm performance by knowledgeexchanging and cooperation within TMT [20]. Given that the individuals most closely influenced by a firm's CEO are its top management team (TMT) members, we focus on the CEO-TMT interface as a salient intervening mechanism. Although scholars, like Ensley et al. (2006) [21] and Noruzy (2013) [22], have verified the mediating role of learning and innovation in the mechanisms of firm performance, they ignored the important role of the knowledge management capabilities of TMT in the relationship between the leadership behavior and firm performance. From the CEO perspective, how to maximize the coordination and application of diversified knowledge of the TMT's members is the key to ensuring the efficient operation of the enterprise. As a new research perspective in the field of 
team knowledge management, the transactive memory system (TMS) proposed, based on the working process of high-performance teams, has attracted more attention from scholars [23]. Transactive memory developed in close relationships is the shared division of cognitive labor with respect to the encoding, storage, retrieval, and communication of information from different knowledge domains [24]. Knowledge in TMS becomes more specialized or "differentiated" among members as a result of the delegation of knowledge responsibilities to different member. Studies from Ren and Argote (2006) [25] and Lewis (2003) [26] show that TMS, as an effective way of team knowledge processing, can bring positive impact on enterprise performance. Therefore, this study introduces TMT's transactive memory systems into the leadership field and explores the role of transactive memory systems of TMT in the relationship between humble CEO leadership behavior and start-up performance.

\subsubsection{The Importance of Strategic Flexibility}

The situation of start-up enterprises becomes increasingly complex as the acceleration of globalization and informatization. Strategic flexibility is a special competitive ability to respond to environmental changes to achieve rapid development through internal structure adjustments and changes [27]. The CEO should dynamically look at the internal and external environment of the start-up and attach more importance to the ability of enterprises to respond to environmental changes. Especially, with China becoming one of the most active economic entities nowadays, the environmental changes met by local start-ups are more serious than before. Importantly, strategic flexibility can stimulate start-ups to overcome inertia dependence as well as improve overall vitality and competitiveness [28]. Thus, strategic flexibility plays a non-negligible role in linking leadership behavior and corporate performance.

In this study, the leadership theory and upper echelons theory are adopted to explore the effect of CEO humility and start-up firm performance by building a moderated mediation model. We used 5-point Likert to obtain first-hand research data and used hierarchical regression analysis to validate this study. The contribution of this research will not only enrich and improve the literature on humility leadership behavior but also respond to the appeal of opening the black box that the CEO's interpersonal dynamics and leadership style may affect corporate innovation performance. It is noticeable that even though this study focuses on the financial performance of start-ups, the theorical analysis of the effect of CEO humility on start-up corporation sustainability validates the statement of Throop (2017) that humility effectively facilitates the transition to a more sustainable economic mode to face complex environmental and social challenges.

The remainder of the paper is organized as described below. Section 2 provides a theoretical background and hypotheses. Section 3 introduces the research method used in this study. Section 4 describes the data analysis and results. Section 5 is the conclusions and discussion.

\section{Theoretical Background and Hypotheses}

\subsection{Humble Leadership Behavior}

Owens and Hekman [29] first proposed the concept of humble leadership behavior, that is, "leading from the ground" or "bottom-up leadership". They pointed out that humility is not an accidental cognitive behavior or short-term emotional expression but an interpersonal interaction pattern that individuals often show and that can be observed by others. Based on the perspective of the leader's behavior, there are three main elements of humble leadership: (i) Admitting their own limitations and deficiencies; that is, leaders dare to admit their weaknesses and errors, and are willing to accept criticisms and suggestions from subordinates. This frank attitude further promotes a good cooperative relationship between leaders and their subordinates. (ii) Appreciating the advantages and contributions of subordinates; that is, leaders can find and appreciate the advantages of subordinates at work and praise and acknowledge employees' contributions. (iii) Being a humble learner and a model for subordinates; that is, the leader is a good "learner" and "listener" showing an open attitude to 
fresh ideas and constructive feedback [30]. Overall, humble leadership behavior means the leader has the characteristics of acknowledging their own limitations and errors, being good at discovering the advantages and contributions of subordinates, and having a humble and learnable personality [31,32].

While some scholars stated that humble leadership can be gradually changed by experience or training, humility is considered as a relatively stable trait [30]. Compared to other traits, such as narcissism, core self-evaluations, and modesty, humble leadership behavior has been discussed theoretically and tested empirically. Nielsen et al. [33] showed that humble leadership behavior can promote employees' recognition and trust in leaders and improve employees' sense of self-efficacy and willingness of devotion. Chiu [34] believed that humble leadership behavior can help increase the subordinate's participation and psychological freedom and can stimulate the generation of shared leadership behavior by accelerating team member interaction. For team-level research, Rego et al. [35] explored the significant impact of humble leadership behavior on team humility, team psychological capital, and team efficiency; Ou et al. [30] found that humble leadership behavior has a significantly positive effect on the performance of TMT. However, current research on the mechanism of humble leadership at the enterprise level is relatively scarce. Zhang [36] studied the impact of humble and narcissistic leadership behavior on firm innovation from the paradox perspective of CEO traits and found that CEOs that are both humble and narcissistic can improve the innovation performance of enterprises.

\subsection{Transactive Memory System (TMS)}

Wegner et al. [37] firstly proposed the definition of TMS and believed that transactive memory is a cognitive division of labor in which team members encode, store, retrieve, and exchange information in different knowledge domains. Based on that, Wegner defined the TMS as the division of cognitive for team members' knowledge, the combination of shared consciousness of where knowledge resides (who knows what), and the sum of personal memory systems and communication activities among team members [37]. Other studies suggested that TMS are knowledge cooperation systems that are formed by organizations in order to accomplish specific tasks in their specific practice and that can enable team members to rely on and trust each other during their work [25]. Later, Lewis [26] further improved the connotation of TMS on the basis of previous studies and regarded it as a cooperative division system of labor for learning, memorizing, and exchanging team knowledge, which emphasized the integrated use of members' distributed domains and the optimization of members' knowledge value.

Although the definitions of TMS are various, existing researches generally divide the TMS into three dimensions, namely specialization, credibility and coordination. (i) Specialization refers to the work division among team members during knowledge processing, which means that knowledge and information held by team members is distributed in different professional fields. (ii) Credibility refers to the degree to which team members trust each other's abilities during the execution of tasks. The higher the degree of trust, the smoother the information communication and knowledge integration among team members. (iii) Coordination refers to degree of mutual assistance and cooperation between team members during the execution of the task. Lewis et al. [38] believed that the interaction and coexistence of these three dimensions is the basis for the existence of TMS and also is an important factor that affects the behavior of team members. Thus, interactions among TMT with TMS are focused between members who hold knowledge relevant to the problem or task. Moreover, the diffusion of responsibility that can occur with behaviorally or socially integrated teams is less likely in teams with transactive memory since different members are held responsible for complementary domains of knowledge and expertise [39].

TMT members for an organization are required to have the ability to access and marshal distinguishable insights and knowledge for exploitation and exploration [40]. The concept of the TMS of TMT is rooted in the above research and specifically refers to a cooperative division of labor system, which is formed among executive members to rely on each other and to obtain knowledge from different domains $[26,36]$. By providing an increasingly detailed directory of where knowledge resides, 
transactive memory facilitates greater recognition and usage of team members' distinct knowledge. In addition, many studies have shown that the TMS, as an effective method of team knowledge processing, can bring positive effects on team performance [41,42]. However, few scholars have explored the important influence of TMS in the field of TMT.

\subsection{CEO Humility Leadership Behavior and Start-Up Enterprise's Performance}

Start-ups, as participants in emerging markets, usually face the status quo of imperfect organizational structure, insufficient resources and technologies, and inadequate standardized management models and present a highly uncertain state within the enterprise [11,43]. In general, young firms have the traits of newness and smallness, so they fail at higher rates than larger and older competitors [44]. Under these circumstances, to surmount the challenges and seize the opportunities, companies are reconfiguring their operating models and raising employees' awareness of sustainability. Meanwhile, the highest leadership (i.e., CEO) ensures that the firm has a particular direction to move toward, which contributes to the organization's profitability and sustainable development within the industry [45]. For a small organization like start-up, a wrong strategic decision by the CEO would bring more serious complications than one in a large enterprise [46]. Moreover, the employees of start-ups enterprises have such low decision-making power and weak awareness of sustainable development that it is difficult for employees to make independent and optimal decisions [47]. Therefore, CEO leadership behavior has become an important determinant in improving start-up enterprise performance. Moreover, humble leadership behavior, which is a "bottom-up" leadership style, is regarded as an ability to motivate employees to be self-driven, self-managing, and collectively assume team responsibility. Therefore, humble CEOs are considered as cooperative, empowering, and virtuous leaders, and can make deep changes in operations and organizational culture $[4,48]$. Overall, CEO's humility not only is a moral habit but also focuses on cognitive/behavioral skills rooted in a deep understanding of a practice. Business leaders (CEO) with the virtue of humility could fully grasp the opportunities of this time to avoid missteps and make scientific decisions to promote the sustainable development of start-ups.

Firstly, the humble CEO dares to admit their faults and limitations [29], which helps to eliminate the tendency of employees to feel uneasy during work. In the development of start-up enterprises, the implementation of any idea is uncertain, and TMTs or entrepreneurial teams are often afraid to innovate because of the fear of making mistakes and being punished by the CEO [43]. The humble CEO actively acknowledges their own shortcomings in the process of enterprise sustainable culture and reduces of subordinates' psychological concerns. Besides, since humble CEO also can admit their dependence on others, they would actively seek help from professionals or subordinates when making some important strategic decisions. This will help start-ups draw scientific development strategies and then improve corporate performance. Secondly, humble CEOs treat subordinates as equal partners and are good at discovering and praising the strengths and contributions of staff. Such behavior sends a signal to staff to participate in the team's decision-making and increases the work commitment of the employees. On the other hand, it also makes employees feel that their knowledge and abilities are valued in the team and then enhance their confidence in their abilities. The support and affirmation from the CEO provide continuous psychological strength for team innovation and then strengthens the intrinsic motivation of employees' innovation, which makes them more resilient and creative [49]. Finally, as a good "scholar" and "listener", the humble CEO continuously improves the trust, identification and loyalty of subordinates to leaders and improves the rationality of entrepreneurial decisions by drawing on wisdom resources from different aspects, which provides the lever of sustainable development [50]. At the same time, humble leaders also encourage team members to mutually provide and listen to feedback and further promote the exchange and sharing of knowledge within the team, which will help generate new ideas in the process of team interaction and then promote entrepreneurial sustainable development performance. According to the existing literature, this study believes that CEO's humble leadership behavior may positively affect the performance of start-ups. More importantly, the humble 
CEO can improve sustainability in the organization by developing a workplace that enhances staff's job satisfaction, increases the security and freedom of employee, and strengthens love and trust for oneself and others [51].

Based on the above arguments, we propose the following:

Hypothesis 1 (H1). The humble leadership behavior of CEOs positively affects the performance of start-ups.

\subsection{CEO's Humble Leadership Behavior and TMT's Transactive Memory System}

TMT is regarded as the direct influence object of CEO's leadership behavior when implementing enterprise strategy. Prior studies have explored the strategic importance of humility $[30,32,36,39]$ and investigated the impact of humble CEO leadership behavior on firm performance from the perspective of TMT [30,34,35]. Nevertheless, some fundamental questions still remain unanswered. TMT is considered as a knowledge-based team that emphasizes team diversity and division of functions, which ensures the efficient operation of the organization. Rationally, how to fully coordinate and utilize the diverse knowledge of the TMT members is an important basis for ensuring the efficient operation of the organization $[52,53]$.

In the vehemently competitive market environment, researchers believed that knowledge is an important organizational resource, and knowledge administration is deemed to enhance firms' competitive capability [54]. However, from empirical results, researchers found that the lack of sharing culture impedes knowledge sharing and transference in organizations. Connelly et al. indicated the organizational knowledge-hiding phenomenon, and they also showed that the interpersonal distrust is related to the hiding behaviors [55]. Leadership behavior is closely related to team cognition [56]. Studies have shown that leadership behavior can significantly affect team's shared mental model [57]. However, the relationship between TMS among top managers and CEO humility is still not clear. As the embodiment of the level for team members' professional knowledge, TMT's TMS is an interdependent cooperative division of labor system formed among team members to acquire, store, and use information or knowledge from different fields [58]. The three core elements of TMS are expertise, credibility, and coordination. Correspondingly, mutual trust, full communication, and cognitive interdependence between team members and top leaders are the prerequisites for the formation of a TMS [59]. Previous studies have shown that humble CEO leadership promotes trust, communication, and mutual awareness among TMT members [60]. Based on them, we expect that the CEO's humble leadership behavior would affect the three core elements of TMS by affecting the TMT interaction process and ultimately promote the formation and development of the TMT's transactive memory system.

Firstly, CEO's humble leadership helps TMTs to develop specialized and differentiated expertise systems. Since the existence of the diversified composition of knowledge and skill within TMT, a good TMT chooses to be "more" or "less" involved in business unit decisions to ensure that everyone is happy to act together. Moreover, the involvement decision depends on the characteristics of the organization. Based on Maslow's Hierarchy of Needs theory [61], the highest demand of individuals in the organization is the need for self-actualization. When CEO attaches great importance to the value and contribution of TMT's members, the executive members will actively use their individual expertise to maximize realization of personal ideals and ambitions. Furthermore, praises and encouragements from humble CEOs to the contributing employees can enhance the sense of self-efficacy of the TMT [30] and help members to develop their expertise, and truly become experts in the field. Secondly, an important manifestation of CEO humility is to acknowledge limitations and mistakes. The humble CEO's sense of self-reflection promotes communication among members of the TMT, which in turn enhances the credibility of the team. By encouraging executives to actively speak up, the CEO and the members of the senior management team can form a high level of trust. At the same time, the humble CEO encourages senior management cooperation and promotes communication among members of 
the senior management team so that members can better understand their professional skills and assign tasks based on expertise. Thirdly, under the leadership of the humble CEO, the TMT member is fully respected, and members share rights, so their status will be more equal, the communication would be smoother, and the team atmosphere would be more open and inclusive. In that team atmosphere, members will increase their psychological security and trust for each other. It can be seen that CEO's humble leadership behavior is likely to help build and develop the team's TMS by enhancing the trust among executive members. Finally, humble CEOs are humble and eager to learn from others, which is conducive to the active expression of subordinates and then promote active knowledge sharing among members. Since knowledge sharing is conducive to the coordination and integration of knowledge among teams, it undoubtedly plays a very important role in the formation of transactive memory systems $[40,62]$.

In summary, the CEO's humble leadership behavior can help senior team members to improve their cognitive abilities, motivates members to strengthen their expertise, accelerates communication and mutual trust among executives, and enhances the degree of knowledge sharing among TMT members. It is conducive to the formation of these three core elements for TMS expertise, credibility and coordination, thereby helping TMTs to establish a higher transactive memory system.

Therefore, we propose the following assumptions:

Hypothesis 2 (H2). The humble leadership behavior of the CEO positively affects the generation of TMS of TMT.

\subsection{TMT's Transactive Memory System and Start-Up Enterprise Performance}

The environment inside and outside the organization faced by start-ups is highly personalized and uncertain. The cognition, values, and judgment of members of TMSs often determine the scientificity and accuracy of strategic decisions of start-ups and ultimately affect the performance of start-ups [63]. Therefore, according to Upper Echelon Theory, we consider that the TMT's TMS can effectively promote the performance of start-up companies.

Firstly, the coordination and expertise of the TMT's TMS is conducive to enhancing the efficiency and effectiveness of collaborative learning, and thus improves enterprise performance [64]. On the one hand, the TMT's TMS can enhance members' knowledge of different areas and can help TMTs integrate knowledge and experience in multiple fields to make better strategic choices and organizational decisions. It is important to mention that knowledge embedded in a TMT's structure and process helps groups apply prior learning to new tasks and develop an abstract understanding of a problem domain, which can be leveraged to created sustainable advantage for the organization [38]. On the other hand, specialization also helps members to allocate cognitive resources more effectively. That means a start-up can draw and integrate information resources in different fields and avoid the neglect to the market environment and competitors' related information [65], which is crucial to the improvement of start-up performance. Secondly, the high trust formed by the TMT's TMS means that members can collaborate highly [66]. With deepening interactions, TMT members can understand each other more and more in detail and can clearly know their expertise areas. In addition, TMS, as an interactive process demanding knowledge, experiences, and skills of organizational members, assists corporate leaders to identify best practices and promotes new ideas and organizational learning, which is an effective group cognitive system as well as a knowledge-sharing structure for organizations to keep competitive advantages. Informed by knowledge-based theory, knowledge is the most important strategic resource leading to long-term, sustainable competitive advantage [67]. Furthermore, with the degree of trust between members gradually deepening, the maturity and stability of TMS become higher. That can enable members to efficiently integrate their own technology, experience, and knowledge, then enhances the overall understanding of the task and environment of the TMT [38], and ultimately effectively improves corporate performance. Importantly, the workplace, full of trust 
and love, can promote TMT member's job satisfaction and corporation sustainability. Finally, once the TMS is formed, the team atmosphere will be harmonious and the degree of satisfaction will naturally increase. Therefore, efficient collaboration among members and reassignment of existing knowledge to launch new products or services will be helpful to improve the performance of the start-up.

In addition, the preceding hypotheses present the relationship between humble CEO leadership, TMT's TMS, and start-up firm performance. Hypothesis 1 shows that CEO humility has a positive relationship with organizational innovation performance. Specifically, research showed that team member familiarity and communication volume and frequency [68] are positively related to TMS development. Moreover, the leadership styles that involve human interaction and encourage participative decision-making processes are positively related to knowledge management [69]. In that context, we propose that TMS of TMT has a mediating effect in the relationship between humble CEO leadership and start-up firm performance.

Accordingly, we propose the following hypotheses:

Hypothesis 3 (H3). The TMS of the TMT team has a significant positive impact on the performance of start-ups;

Hypothesis 4 (H4). The TMT's TMS plays a mediating role between the relationship between CEO humility and the performance of start-ups.

\subsection{Moderating Role of Strategic Flexibility}

CEO's cognitive ability and leadership behavior are considered to have a positive impact on entrepreneurial performance [43] and the TMT's TMS plays a bridge role in the relationship between CEO leadership behavior and entrepreneurial performance [63]. However, self-determination theory states that external environmental factors can not only affect an individual's basic psychological needs but also affect their attitudes and behaviors [70]. Therefore, we believe that the role of humble leadership may be affected by other contextual factors in the organization. From the perspective of environmental complexity, the ability of enterprises to respond to environmental changes plays an increasingly important role in start-up firm survival and sustainability. That is because the survival environment of start-up companies is complex and changeable, strategic flexibility is a dynamic ability of an enterprise to respond to environmental changes and sustainable development. This ability urges companies to continuously adjust their strategic plans, resource allocation, and investment strategies to adapt to the change of external environment [27]. Therefore, this study considers the moderating role of strategic flexibility in the impact of humble CEO leadership behavior on TMT's TMS and entrepreneurial enterprise performance.

The typical characteristic of strategic flexibility is stronger organizational adaptability. Since humble leadership behavior of CEOs is seen as the key to the success for start-ups, strategic flexibility should be considered as the key to adapt to environmental changes. In the process of start-up development, strategic flexibility can strengthen the CEO who integrally utilizes internal and external resources and can seize opportunities to innovate and then improve innovation performance. The higher degree of strategic flexibility for the start-up means that the company has a higher strategic vision and a stronger spirit of innovation, masters the initiative in the game with competitors, and keeps the products and ideas advanced [71]. To some extent, high strategic flexibility can activate team members' innovation potential and bring work pride and satisfaction for them. Moreover, the CEO's humble leadership reinforces the need for employees to be respected, which increases their innovation initiative and work initiative. Therefore, the higher the degree of strategic flexibility, the higher the enthusiasm and innovation of TMT members as well as and grass-roots employees for firms, ultimately promoting corporate performance. Besides, companies with high strategic flexibility have greater initiative in acquiring new resources, which is conducive to efficient innovation and 
performance improvement for start-up companies. That is because humble CEO provides a relaxed working environment for employees where they can search for new resources outside the organization.

On the other hand, strategic flexibility can enable firms to dynamically manage their resources for adapting to high velocity environments. Besides, it also can help firms achieve the full potential of their key resources [72]. However, strategic flexibility requires an integrative series of abilities to obtain, explain, share, and utilize knowledge by seeing environments carefully and deeply so that the firm can take timely and appropriate actions. Managing knowledge is an inseparable component of strategic flexibility [73]. Humble CEOs are accustomed to cooperating and communicating with their subordinates, especially with TMT members. In addition, the CEO's cognitive ability can identify useful information for strategic decisions from an uncertain environment and encourage TMT members to share knowledge [74]. Moreover, the TMT's TMS enables executive members to expand different channels to obtain knowledge and other information resources. The more flexible the corporate strategy is, the more TMT members can enrich their perspectives from different perspectives, which is conducive to the establishment of a higher TMS. Moreover, the team atmosphere created by the leadership behavior of humble CEOs has inspired the enthusiasm and willingness of team members to participate in discussions. Because strategic flexibility combines flexibility and diversity, senior management teams can draw on and integrate knowledge resources through their keen observation and learning ability, which is useful to the formation of a high-level TMS, which in turn promotes start-ups to seize market opportunities and gain competitive advantages in a fiercely competitive environment.

Finally, in a corporate environment with high strategic flexibility, the behavior of CEOs and TMT members to hide their knowledge is inhibited. That is because, with the high flexibility of the corporate strategy, the sense of responsibility of the CEO and TMT members can be stimulated so that they can maintain enough motivation to cooperate and willingness to share when facing new opportunities brought by the market. Sharing knowledge and information for TMT members can broaden their perspective in analyzing and solving problems, improve the execution of strategy implementation, reduce the time spent in decision-making, and ultimately improve corporate performance.

Based on above arguments, we propose the following:

Hypothesis 5 (H5). Strategic flexibility plays a moderating role in the relationship between the CEO's humble leadership behavior and the TMT's TMS;

Hypothesis 6 (H6). Strategic flexibility plays a moderating role in the relationship between CEO's humble leadership behavior and start-up enterprise performance.

Based on the above literature analysis, the theoretical model of this paper is shown in Figure 1.

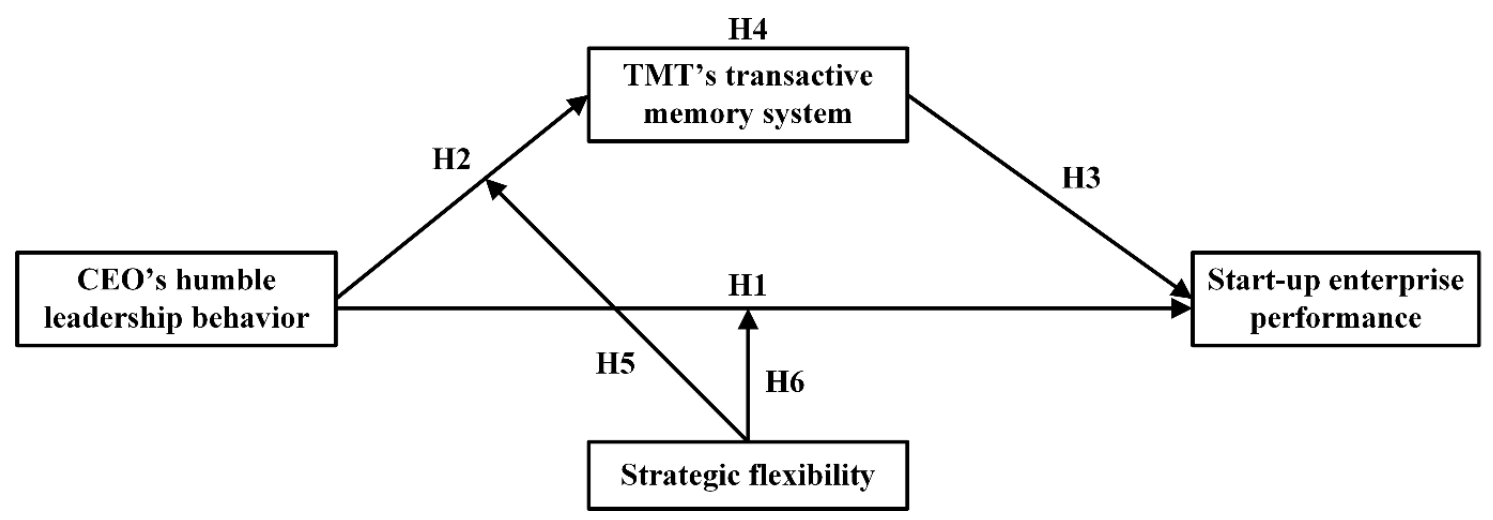

Figure 1. Proposed model and hypotheses. 


\section{Research Methods}

\subsection{Data and Method}

In order to test these hypothesizes, we conducted a questionnaire survey with managers including CEOs of start-ups. For the definition start-up, Luger (2005) [75] defined the start-up firm by using three different definitional criteria: "new", "active", and "independent". Virtually, all studies of start-up firms use "new" as the main discriminator. Debrulle and Maes (2014) [76] and Peterson and Myrowitz (2008) [10] define firms that have been in business for one to five years, are active with various economic sectors, and have a minimum of one and a maximum of 49 employees as start-ups. Therefore, we follow the previous studies and employ firm age (less 5 years) as the criterion to choose the sample firms. Prior to administering the questionnaire, we asked two Professors in the field of human resources management to review the items and indicate to us whether the questions were clear and reflected the constructs they were intended to measure. Following this procedure, we made minor revisions to improve the clarity of certain items. Besides, in our questionnaire, we explained the importance of truthful answers for scientific research and ensured confidentiality by guaranteeing that only the researchers would see individual answers and that the company would receive only a company-level summary, which is an effective means to access high-quality data. For the data collection, we employ three approaches to get enough and valid data. The first wave data is collected by conducting in-depth field investigations of firms during the period of consultation and training for start-ups. We interviewed 13 CEOs face-to-face and distributed questionnaires to obtain 13 valid data, and questionnaires were issued to 61 senior executives and 148 middle-level managers from these companies at the scene, obtained the 199 valid feedback data. In all, we obtained 212 valid data from field interviews. Secondly, we asked the help from alumni of executive MBA programs in putting us in contact with their firms' CEOs and TMT members. We sent 110 questionnaires and obtained 89 valid responses. The third wave data are collected from 100 start-up firms located in China's national-level start-up park. With the permission of the senior executives, we sent questionnaires to TMT members by email. Two weeks later we received 143 responses. Moreover, in order to ensure the authenticity of the data, we made follow-up phone calls to confirm the result of the questionnaire and obtained 99 valid data. Totally, the data collection lasted 4 months, a total of 532 questionnaires were distributed, and 400 valid questionnaires were obtained. The response rate was $75.19 \%$.

Among that, the average age of these firms is 3.4 years, ranking from 8 months to 5 years; the ownership of the enterprise is mainly private, accounting for $68.32 \%$. The descriptive statistics of the sample are as follows: for the gender of CEO, $80.5 \%$ are male and $19.5 \%$ are female. With regards to age for CEO, $31.8 \%$ are 30 to 40 years old, $45 \%$ are 41 to 50 years old, and $23.2 \%$ are 50 years old and above. As for the tenure of CEO, $32.2 \%$ are less than 3 years, and $48.5 \%$ are 3 to 5 years, and more than 5 years accounted for $19.3 \%$. In terms of CEO's education background, $18.3 \%$ have a junior college degree or below, $45.3 \%$ have a bachelor's degree, and $36.4 \%$ have a master's degree or above. Among the executive sample, $27 \%$ have a junior college degree or below, $41 \%$ have a bachelor's degree, and $32 \%$ have a master's degree or above. In the pool sample, for the distribution of industries, $33.2 \%$ are in electronic information technology, $14.8 \%$ are in biotechnology and medicine, $27.6 \%$ are in software design and manufacturing, $13.6 \%$ are in new materials technology, and $10.8 \%$ are in other industries.

\subsection{Variables}

Most of the items in the questionnaires were originally developed by other authors in English language. In accordance with convention [77], we translated the items into Chinese and then back-translated them into English to ensure that the content was accurately represented in the Chinese items. The questions are based on 5-point Likert scales ranging from 1 (strongly disagree) to 5 (strongly agree) points. Table 1 shows the measurement items used to visualize the latent variables. 
Table 1. Measurement items, loadings, validity, and reliability.

\begin{tabular}{|c|c|c|c|c|c|}
\hline Variables and Scale Items & $\begin{array}{l}\text { Standardized } \\
\text { Loading }\end{array}$ & $\begin{array}{l}\text { Cronbach's } \\
\text { Alpha }\end{array}$ & $\begin{array}{l}\text { Average Variance } \\
\text { Extracted }\end{array}$ & $\begin{array}{l}\text { Composite } \\
\text { Reliability }\end{array}$ & KMO \\
\hline CEO's humble leadership behavior & & 0.868 & 0.717 & 0.910 & 0.808 \\
\hline 1. Our CEO(I) shows appreciation for the unique contributions of others $[29,30]$. & 0.777 & & & & \\
\hline Our CEO(I) is (am) willing to listen to others' ideas [30]. & 0.885 & & & & \\
\hline Our CEO(I) takes notice of others' strengths [29]. & 0.878 & & & & \\
\hline 4. Our CEO(I) has transcendent self- concept [30]. & 0.843 & & & & \\
\hline TMT's transactive memory system & & 0.862 & 0.708 & 0.906 & 0.818 \\
\hline 1. I trusted that other members' knowledge about the project was credible [26]. & 0.878 & & & & \\
\hline Different team members are responsible for expertise in different areas [26]. & 0.882 & & & & \\
\hline Each team member has specialized knowledge of some aspect of our project [26]. & 0.849 & & & & \\
\hline $\begin{array}{l}\text { 4. Our team worked together in a well-coordinated fashion and had very few } \\
\text { misunderstandings about what to do [26]. }\end{array}$ & 0.839 & & & & \\
\hline Strategic flexibility & & 0.884 & 0.743 & 0.920 & 0.815 \\
\hline $\begin{array}{l}\text { 1. When encounter difficult and new circumstances, the firm does not feel worried or } \\
\text { threatened [78]. }\end{array}$ & 0.830 & & & & \\
\hline The firm is in an industry where key technologies are updated quickly [27]. & 0.858 & & & & \\
\hline The firm has ability to quickly and effectively readjust its strategic positioning [78]. & 0.859 & & & & \\
\hline 4. The firm can quickly find new resources or new combinations of existing resources [27]. & 0.817 & & & & \\
\hline Start-up enterprise performance & & 0.915 & 0.705 & 0.935 & 0.854 \\
\hline 1. Compared with rival, the firm has a higher market share [80]. & 0.844 & & & & \\
\hline Compared with rival, the firm has higher net profit rate [79]. & 0.892 & & & & \\
\hline Compared with rival, the firm has higher return on investment [80]. & 0.903 & & & & \\
\hline Compared with rival, the firm has higher return on assets (ROA) [79]. & 0.882 & & & & \\
\hline Compared with rival, the firm has higher new product and service growth rates [80]. & 0.751 & & & & \\
\hline Compared with rival, the firm has higher market growth rate [80]. & 0.752 & & & & \\
\hline
\end{tabular}


(1) CEO's humble leadership behavior: This paper adopts a scale developed by Owens et al. [29] and $\mathrm{Ou}$ et al. [30], including whether the CEO can objectively evaluate himself and admit his mistakes, appreciate the strengths of others, and be open to others' ideas and others and designed 4 items, such as "Our CEO (I) shows appreciation for the unique contributions of others", "Our CEO (I) is (am) willing to listen to others' ideas".

(2) TMT's transactive memory system (TMT's TMS): we adopted a scale developed by Lewis [26] including the three dimensions of specialization, credibility, and coordination and designed 4 questions, such as "I trusted that other members' knowledge about the project was credible", "Different team members are responsible for expertise in different areas", and "Each team member has specialized knowledge of some aspect of our project".

(3) Strategic flexibility. The variable was measured by using a scale developed by Nadkarni and Narayanan [27] and Young-Ybarra and Wiersema [78]. We designed 4 items, such as "When encounter difficult and new circumstances, firm does not feel worried or threatened", "Firm has the ability to quickly and effectively readjust its strategic positioning".

(4) Start-up enterprise performance: The measurement of corporate performance mainly adopted the scale developed by Li et al. [79] and Thongsri and Chang [80]. We designed 6 items from a financial and growth perspective and used the comparison value with other companies to better test the firm's performance. The indices of financial performance mainly contain market share, net profit rate, and return on investment. Moreover, the indices for growth performance are sales growth rate, market share growth rate, and new product or new service growth rate.

(5) Control variables: This paper selects the firm size, firm age, TMT education, and CEO tenure as the control variables. For different size companies, leadership styles that CEOs adopt are different, and in turn, the impacts on innovation performance also are different. The age of an enterprise is also an important factor affecting the innovation performance of start-ups. In addition, executive education background and CEO tenure also affect the firm's deployment of corporate strategy and then have a significant impact on firm performance. Therefore, in order to improve the fitting degree of the research model, the above-mentioned four important background information items that influence the behavior of start-up enterprises are treated as control variables.

\section{Data Analysis and Results}

\subsection{Reliability and Validity Tests}

Principal component analysis was performed on the questionnaire data by SPSS and AMOS statistical software, and the maximum variance method was used to perform the rotation factor load analysis. The internality of each item was tested using the Cronbach' $\alpha$ coefficient, and a reliability coefficient was constructed to test the latent variables and internal quality.

Based on the rotation solution with eigenvalues greater than 1, KMO values are all above 0.8, the AVE of the latent variable is greater than 0.60 and the CR values are greater than 0.90 , indicating that the scale has good convergent validity. Moreover, the test results show the questionnaire data is suitable for factor analysis (Table 1). In addition, Fornell (1981) believed that the square of the variance of each variable is greater than the correlation coefficient of the row and column, indicating that the measurement had good discriminant validity [81]. It can be seen from Table 2 that the correlation coefficients between the variables are smaller than the square root of the average extraction variance (bold value on the diagonal), indicating that the variables have good discrimination validity. 
Table 2. Mean, standard deviation, and correlation coefficients of variables.

\begin{tabular}{|c|c|c|c|c|c|c|c|c|}
\hline Variable & 1 & 2 & 3 & 4 & 5 & 6 & 7 & 8 \\
\hline 1 Firm age & 1 & & & & & & & \\
\hline 2 TMT education & $0.296^{* *}$ & 1 & & & & & & \\
\hline 3 Firm size & -0.065 & $-0.066^{* *}$ & 1 & & & & & \\
\hline 4 CEO tenure & 0.051 & -0.058 & $-0.392 * *$ & 1 & & & & \\
\hline $\begin{array}{l}5 \text { CEO's humble } \\
\text { leadership behavior }\end{array}$ & -0.053 & -0.061 & $0.324^{* *}$ & $-0.193^{* *}$ & 0.847 & & & \\
\hline 6 TMT's TMS & 0.003 & -0.018 & $0.203^{* *}$ & $-0.155^{* *}$ & $0.646^{* *}$ & 0.841 & & \\
\hline 7 Strategic flexibility & $-0.070 *$ & -0.114 & 0.029 & -0.010 & $0.218^{* *}$ & $0.359 * *$ & 0.862 & \\
\hline $\begin{array}{l}8 \text { Start-up enterprise } \\
\text { performance }\end{array}$ & -0.013 & -0.018 & $-0.340 * *$ & $-0.297^{* *}$ & $0.556^{* *}$ & $0.595^{* *}$ & $0.272 * *$ & 0.840 \\
\hline Means & 2.01 & 1.59 & 5.62 & 2.29 & 3.68 & 3.77 & 3.39 & 3.51 \\
\hline SD & 0.751 & 0.871 & 1.120 & 0.802 & 0.844 & 0.810 & 0.913 & 0.817 \\
\hline
\end{tabular}

\subsection{Descriptive Statistical Analysis}

Table 2 below provides descriptive statistics and bivariate correlations for the study variables. The results of correlation coefficients in Table 2 show that start-up enterprise performance is significantly correlated with humble CEO leadership behavior $(\beta=0.556, \mathrm{p}<0.01)$. Although there is a high correlation between independent variable and dependent variables, it is still less than the statistical standard $(<0.7)$ and is not highly correlated $[82,83]$. Moreover, TMT's transactive memory system and strategic flexibility also have significantly positive impact on start-up enterprise performance $(\beta=0.595, p<0.01 ; \beta=0.272, p<0.01)$. The correlation examination is basically consistent with the hypotheses proposed in the previous discussion and provides preliminary support for subsequent hypothesis testing.

\subsection{Hypothesis Tests and Result Analysis}

This study used multiple regression analysis to test hypotheses by using SPSS 23.0. In order to ensure the reliability of the study, the collinearity of all independent variables was diagnosed by the variance expansion factor (VIF). The results show that the VIF values of the main variables are below 2 and far below the critical value of 5 . Therefore, there is no strong multicollinearity problem between independent variables in this study.

\subsubsection{The Main Effect Tests}

Hypothesis1 predicts that the CEO's humble leadership behavior positively affects start-up enterprise performance. First, this paper examined the impacts of the control variables (firm age, TMT members' education, firm size, CEO tenure) on TMT's TMS and start-up enterprise performance, defining M1 and M3 respectively. M1 shows that the regression coefficient of TMT education on TMT's transactive memory system is $-0.107(\mathrm{p}<0.1)$. It is because the members with higher education degree tend to protect their knowledge and do not like to share their core knowledge and skills with others. Both firm age and firm size in M3 are significantly positive to start-up enterprise performance. Given the economies of scale, human resources and knowledge resources become richer with the increase in firm size. The increase in core resources of the firm will further improve start-up performance. On the contrary, CEO tenure is significantly negative correlated to start-up enterprise performance. The potential reason is that the longer the CEO's tenure is, the more power he/she has, even exclusive power. It is not conducive to the TMT fully play its role in strategic decision-making. Besides, is also difficult for the CEO to obtain sincere suggestions from subordinates, resulting in the slow development of the entrepreneurial enterprise. As a result, a CEO's long tenure is not conducive to the improvement of enterprise performance. Model 2 shows that a CEO's humble leadership behavior significantly and positively affects the TMT's transactive memory system at the alpha level of $0.001(\beta=0.248)$ 
which validates $\mathrm{H} 2$. This is because humble $\mathrm{CEO}$ leadership promotes trust, communication, and mutual awareness among TMT members. Moreover, a humble CEO encourages senior management cooperation and promotes communication among members of the senior management team so that members can better master their professional skills and assign tasks based on expertise. Therefore, CEO's humble leadership behavior can help to build and develop the team's TMS by enhancing the trust among executive members. Model 3 to model 6 in Table 3 are used to test the main effect of TMT's TMS and CEO humility on start-up enterprise performance. Model 4 reveals that the CEO's humble leadership behavior is positively related to entrepreneurial performance $(\beta=0.472, p<0.001)$, which supports H1. The empirical results are in accordance with the research conclusions of Ou et al. [30] and Jiang et al. [31]. CEO's humble leadership can improve the trust, identification, and loyalty of subordinates to leaders; increase the subordinates' job satisfaction to the organization and promote the creativity of employees. In addition, CEO's humble leaders not only affect their individual followers but can also shape their organization's culture by building a new shared vision and commitment of their followers. In Model 5, we can see that transactive memory systems of TMT positively affect start-up enterprise performance $(\beta=0.238, \mathrm{p}<0.001)$, and $\mathrm{H} 3$ is supported. The transactive memory system of TMT ensures a high degree of teamwork among the members. This kind of teamwork enables TMT's members to integrate their own resources, skills, experience, and knowledge to enhance the TMT member's understanding of the task and working environment and ultimately achieve an effective improvement of organizational performance.

Table 3. The mediator of transactive memory systems of top management team (TMT).

\begin{tabular}{|c|c|c|c|c|c|c|}
\hline \multirow{3}{*}{ Variable } & \multicolumn{6}{|c|}{ Dependent Variable } \\
\hline & \multicolumn{2}{|c|}{ TMT's Transactive Memory Systems } & \multicolumn{4}{|c|}{ Start-Up Enterprise Performance } \\
\hline & M1 & M2 & M3 & M4 & M5 & M6 \\
\hline Firm age & -0.047 & -0.042 & $0.021 * *$ & -0.030 & 0.032 & 0.036 \\
\hline TMT education & $-0.107 *$ & $-0.097^{*}$ & -0.016 & 0.003 & 0.009 & 0.018 \\
\hline Firm size & 0.014 & -0.040 & $0.192 * * *$ & $0.090^{* *}$ & $0.189^{* * *}$ & $0.096^{* *}$ \\
\hline CEO tenure & -0.009 & 0.013 & $-0.200 * * *$ & $-0.159 * * *$ & $-0.198^{* * *}$ & $-0.161^{* * *}$ \\
\hline \multicolumn{7}{|l|}{ Independent variables } \\
\hline $\begin{array}{c}\text { CEO's humble leadership } \\
\text { behavior }\end{array}$ & & $0.248^{* * *}$ & & $0.472^{* * *}$ & & $0.434^{* * *}$ \\
\hline \multicolumn{7}{|l|}{ Mediating variables } \\
\hline TMT's TMS & & & & & $0.238^{* * *}$ & $0.155^{* * *}$ \\
\hline $\mathrm{R}^{2}$ & 0.015 & 0.061 & 0.148 & 0.359 & 0.217 & 0.387 \\
\hline Adj. $R^{2}$ & 0.005 & 0.050 & 0.139 & 0.351 & 0.207 & 0.378 \\
\hline $\mathrm{F}$ & $1.486^{* * *}$ & $5.157 * * *$ & $17.120^{* * *}$ & $44.098^{* * *}$ & $21.891^{* * *}$ & $41.361^{* * *}$ \\
\hline
\end{tabular}

\subsubsection{The Mediating Effect Test}

Given that $\mathrm{H} 4$ proposes that the transactive memory systems of TMT plays a mediating role in the relationship between CEO's humble leadership behavior and start-up enterprise performance, we adopted two approaches to test this possible mediating effect. In the first approach, we adopted the traditional mediating effect testing procedure proposed by Baron and Kenny (1986) [84]. First, by combining the results from $\mathrm{H} 1$ and $\mathrm{H} 4$, we can find that the significant positive relationship between CEOs humble leadership behavior and start-ups performance becomes weaker (from $\beta=0.472$, $\mathrm{p}<0.001$ in Model 4 to $\beta=0.434, \mathrm{p}<0.001$ in Model 6). The change indicates that transactive memory systems of TMT partially mediate the relationship between CEOs humble leadership behavior and start-ups performance and suggests that CEOs humble leadership behavior can directly affect start-up performance or partially exert impact on firm performance via adopting transactive memory systems of TMT as the mediating means. Therefore, $\mathrm{H} 4$ is confirmed.

The second approach to test the linear mediating effect is Bootstrapping test proposed by Hayes (2009) [85]. We set bootstrap sample size to 1000, used the non-parametric percentile method for bias correction, and set a 95\% confidence interval. The empirical results obtained are shown in Table 4 . The 
confidence intervals of all the effects of bootstrapping did not contain 0 , indicating that the Transactive memory systems of TMT play a partial mediating role in the relationship between CEO's humble leadership behavior and start-up enterprise performance. Meanwhile, the Z-value from indirect effect was 3.026 ( $p<0.001)$, which is greater than 1.96 , which further validated $\mathrm{H} 4$.

Table 4. The mediator of transactive memory systems of TMT (Bootstrapping test).

\begin{tabular}{ccccc}
\hline & & & \multicolumn{2}{c}{ Bootstrapping } \\
\cline { 2 - 4 } IV-M-DV & Estimate & SE & LLCI & ULCI \\
\cline { 3 - 4 } & & & 0.3907 & 0.5538 \\
Total effect & 0.472 & 0.0415 & 0.0160 & 0.0752 \\
Indirect effect & 0.038 & 0.0145 & 0.3520 & 0.5155 \\
Direct effect & 0.434 & 0.0416 & \\
\hline
\end{tabular}

Notes: IV represents CEO's humble leadership behavior; M represents transactive memory systems of TMT; DV represents start-up enterprise performance.

\subsubsection{The Moderating Effect Tests}

Before testing the moderating effect, the independent variables and the moderate variables were centralized to prevent multicollinearity between variables. $\mathrm{H} 5$ proposes that the positive effect of CEO's humble leadership behavior on the TMT's TMS will increase with a high degree of strategic flexibility. Therefore, we introduce an interaction term between humble CEO leadership behavior and strategic flexibility into the model to verify this moderating effect. It can be seen from Model 4 in Table 5 that the regression coefficient of the interaction item between CEO's humble leadership behavior and strategic flexibility is not significant $(\beta=0.163 n, s)$, which indicates that strategic flexibility does not play a moderating role in the relationship between CEO's humble leadership behavior and TMT's transactive memory system. Therefore, Hypothesis 5 has not been verified. The possible reason is that strategic flexibility reflects the flexibility and responsiveness of an organization's response to environmental changes and has a very weak impact on the knowledge of TMT. As a result, strategic flexibility is not significant in the impact process of CEO leadership on TMT's transactive memory systems.

Table 5. The moderating effect of strategic flexibility.

\begin{tabular}{|c|c|c|c|c|c|c|c|c|c|}
\hline \multirow{2}{*}{ Variable } & \multicolumn{4}{|c|}{ TMT's Transactive Memory Systems } & \multicolumn{5}{|c|}{ Start-up Enterprise Performance } \\
\hline & M1 & M2 & M3 & M4 & M5 & M6 & M7 & M8 & M9 \\
\hline \multicolumn{10}{|l|}{ Control variables } \\
\hline Firm age & -0.047 & -0.042 & -0.058 & -0.000 & $0.021 * *$ & -0.030 & 0.015 & -0.001 & 0.004 \\
\hline TMT education & $-0.107^{*}$ & -0.097 * & $-0.100 *$ & $0.057^{* *}$ & -0.016 & 0.003 & 0.001 & 0.011 & 0.016 \\
\hline Firm size & 0.014 & -0.040 & -0.034 & -0.011 & $0.192 * * *$ & $0.090 * *$ & $0.095 * *$ & $0.112 * * *$ & $0.112 * * *$ \\
\hline CEO tenure & -0.009 & 0.013 & -0.030 & -0.003 & $-0.200 * *$ & $-0.159 * * *$ & $-0.143 * *$ & $-0.139 * *$ & $-0.114 * *$ \\
\hline Independent variable & & & & & & & & & \\
\hline $\begin{array}{c}\text { CEO's humble leadership behavior } \\
\text { Mediating variable }\end{array}$ & & $0.248^{* * *}$ & -0.019 & $-0.643 * *$ & & $0.472 * * *$ & $0.223^{* * *}$ & $-0.278^{*}$ & -0.239 \\
\hline $\begin{array}{c}\text { TMT's TMS } \\
\text { Moderating variable }\end{array}$ & & & & & & & & & $0.061 *$ \\
\hline $\begin{array}{l}\text { Strategic flexibility } \\
\text { Interaction }\end{array}$ & & & $0.431^{* *}$ & $-0.152 * * *$ & & & $0.402 * * *$ & -0.065 & -0.056 \\
\hline$C E O \times S F$ & & & & 0.163 & & & & 0.133 ** & $0.121 * *$ \\
\hline$R^{2}$ & 0.015 & 0.061 & 0.146 & 0.166 & 0.148 & 0.359 & 0.451 & 0.467 & 0.471 \\
\hline Adj. $R^{2}$ & 0.005 & 0.050 & 0.133 & 0.151 & 0.139 & 0.351 & 0.443 & 0.458 & 0.460 \\
\hline F-value & $1.486^{* * *}$ & $5.157^{* * *}$ & $11.195^{* * *}$ & $11.152 * * *$ & $17.120^{* * *}$ & $44.098^{* * *}$ & $53.795 * * *$ & $49.089 * * *$ & $43.507 * * *$ \\
\hline
\end{tabular}

Similarly, Hypothesis 6 predicts that the strategic flexibility positively moderates the relationship between CEO's humble leadership behavior and start-up enterprise performance. According to model 8 in Table 5, the interaction term of independent variable (CEO's humble leadership behavior) and moderating variable (strategic flexibility) exerted a significant positive effect on the dependent variable 
(start-up enterprise performance) $(\beta=0.133, \mathrm{p}<0.001)$, which validate $\mathrm{H} 6$. That is, the higher the degree of strategic flexibility, the more significant the positive relationship between CEO's humble leadership behavior and start-up enterprise performance. That is because, with the high flexibility of the corporate strategy, the CEO prefers to improve the execution of strategy implementation, reduce the time spent in decision-making, and ultimately improve corporate performance.

In order to further verify the moderating effect of strategic flexibility in the relationship model, we drew Figure 2 with 1 standard deviation above the mean and 1 standard deviation below the mean, respectively. Figure 2 shows that the higher the strategic flexibility, the stronger the positive impact of humble leadership behavior on start-up enterprise performance and the lower the strategic flexibility, the weaker the positive impact of CEO's humble leadership behavior on start-up enterprise performance. Hence, H6 is supported.

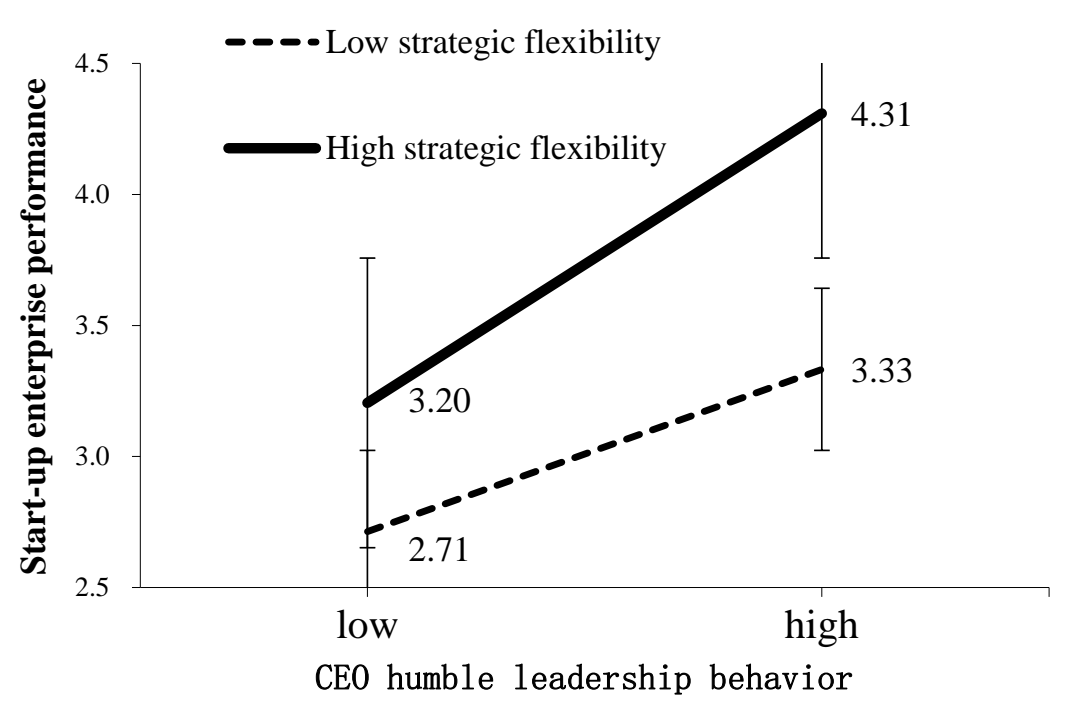

Figure 2. The moderating effect of strategic flexibility.

\subsection{Robustness Tests}

In order to further verify the credibility of this study, we selected the data obtained from 212 field interviews to conduct a robustness test. This study first tests the robustness of the main and mediating effects proposed by H 1-4 and then tests whether Hypothesis 6 can be validated.

When testing the mediating effect of the TMT's TMS between the CEO's humble leadership behavior and the performance of entrepreneurial enterprises, we used the method of $95 \%$ confidence interval and standard error proposed by Preacher et al. [86] (see Table 6). First, the regression coefficient between humble CEO leadership behavior and start-up performance is significant $(\beta=0.416, t=7.306$, $\mathrm{p}<0.001$ ), indicating that Hypothesis 1 is supported. Second, the CEO's humble leadership behavior significantly and positively impacts TMT's TMS $(\beta=0.251, \mathrm{t}=3.111, \mathrm{p}<0.01)$ and the $95 \%$ confidence interval is [0.0920, 0.4103], excluding the zero point. Hence, H2 is verified. Finally, the regression coefficient of the transactive memory systems of TMT and entrepreneurial performance is significant $(\beta=0.110, t=2.297, p<0.1)$ and $95 \%$ confidence interval is $[0.0156,0.2050]$, excluding the zero point. Therefore, Hypothesis 3 is supported. We use the Bootstrapping method to test mediating effect of the TMT's by setting that the number of bootstrap samples is 1000. The test results show that the indirect effect coefficient is significant $(\beta=0.028)$, and the $95 \%$ confidence interval is $[0.0002,0.0790]$, excluding the zero point. Therefore, $\mathrm{H} 4$ is supported. 
Table 6. The results of mediation regression.

\begin{tabular}{|c|c|c|c|c|c|c|}
\hline \multirow{2}{*}{ Variable } & \multirow{2}{*}{ Coefficient } & \multirow{2}{*}{ SE } & \multirow{2}{*}{ T-Value } & \multirow{2}{*}{ P-Value } & \multicolumn{2}{|c|}{ Confidence Interval } \\
\hline & & & & & LLCI & ULCI \\
\hline \multicolumn{7}{|c|}{ Outcome variable: Transactive memory systems of TMT } \\
\hline Constant & 3.253 & 0.720 & 4.517 & 0.000 & 1.8331 & 4.6728 \\
\hline IV & 0.251 & 0.081 & 3.111 & 0.002 & 0.0920 & 0.4103 \\
\hline Firm age & -0.043 & 0.081 & -0.5346 & 0.593 & -0.2034 & 0.1167 \\
\hline TMT education & -0.088 & 0.073 & -1.192 & 0.2347 & -0.2458 & 0.0728 \\
\hline Firm size & -0.034 & 0.122 & -0.279 & 0.779 & -0.274 & 0.206 \\
\hline CEO tenure & -0.034 & 0.122 & -0.279 & 0.779 & -0.274 & 0.206 \\
\hline \multicolumn{7}{|c|}{ Outcome variable: Start-up enterprise performance } \\
\hline Constant & 1.635 & 0.520 & 3.143 & 0.002 & 0.6093 & 2.6610 \\
\hline M & 0.110 & 0.048 & 2.297 & 0.023 & 0.0156 & 0.2050 \\
\hline IV & 0.416 & 0.057 & 7.306 & 0.000 & 0.3037 & 0.5281 \\
\hline Firm age & 0.037 & 0.056 & 0.658 & 0.511 & -0.0735 & 0.1472 \\
\hline TMT education & 0.049 & 0.051 & 0.957 & 0.339 & -0.0515 & 0.1487 \\
\hline Firm size & 0.041 & 0.056 & 0.726 & 0.469 & -0.0696 & 0.1506 \\
\hline CEO tenure & -0.186 & 0.084 & -2.215 & 0.028 & -0.3511 & -0.0204 \\
\hline \multicolumn{7}{|c|}{ Direct effect of CEO's humble leadership behavior on start-up enterprise performance } \\
\hline \multirow{2}{*}{\multicolumn{2}{|c|}{ Coefficient }} & \multirow{2}{*}{ SE } & \multirow{2}{*}{ T-value } & \multirow{2}{*}{ P-value } & \multicolumn{2}{|c|}{ Confidence interval } \\
\hline & & & & & LLCI & ULCI \\
\hline 0.4 & & 0.057 & 7.306 & 0.000 & 0.3037 & 0.5281 \\
\hline \multicolumn{7}{|c|}{ Indirect effect of CEO's humble leadership behavior on start-up enterprise performance } \\
\hline \multirow{2}{*}{\multicolumn{2}{|c|}{$\begin{array}{c}\text { Coefficient } \\
0.028\end{array}$}} & SE & \multirow{2}{*}{\multicolumn{2}{|c|}{$\begin{array}{c}\text { LLCI } \\
0.0002\end{array}$}} & \multicolumn{2}{|c|}{ ULCI } \\
\hline & & 0.020 & & & & \\
\hline
\end{tabular}

Notes: N = 212, IV represents CEO's humble leadership behavior; M represents transactive memory systems of TMT.

In order to test whether the moderating effect of $\mathrm{H} 6$ is robust, we use hierarchical regression analysis. It can be found that the results of the main models are all significant, which is consistent with the above analysis and only slightly fluctuated at the significance level (see Table 7). Therefore, this model has certain robustness.

Table 7. The moderator of strategic flexibility (Robustness tests).

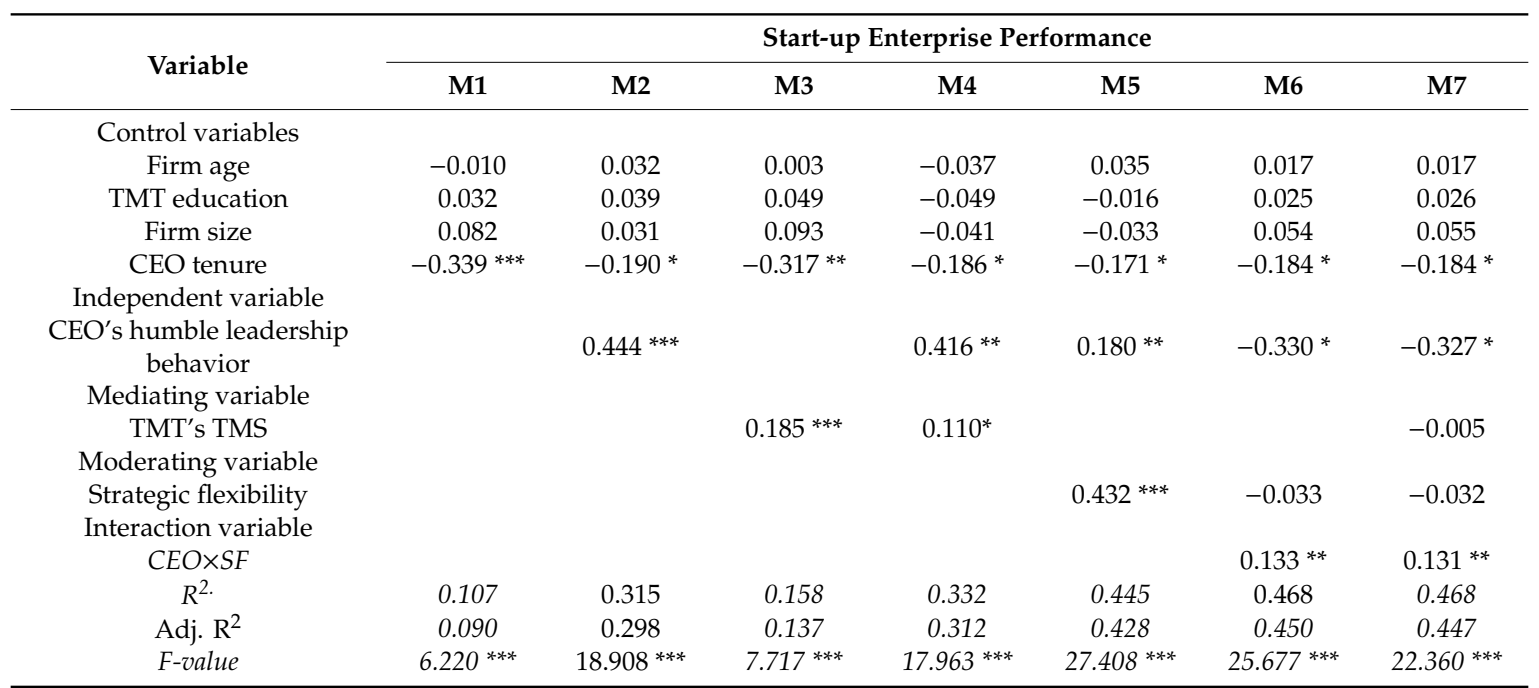

Notes: $\mathrm{N}=212,{ }^{*}$ Significant at the 0.1 level, ${ }^{* *}$ Significant at the 0.01 level, ${ }^{* * *}$ Significant at the 0.001 level; CEO *SF represents CEO's humble leadership behavior * Strategic flexibility. 


\section{Research Conclusion and Discussion}

\subsection{Research Conclusion}

This research study takes start-up enterprise as the research object and empirically analyzes the impact of CEO humility on start-up enterprise performance. The humble CEO leadership not only can improve start-up firm performance but also can promote the firm's sustainable development. That is because the trust employees place in an organization's leadership is essential for companies to achieve their sustainability goals (Lacy et al., 2009) [50], and trustworthiness has been found to be a key attribute of leaders in sustainable organizations (Velsor et al., 2009) [87]. In this study, we explore the how CEO humility affects a start-up firm's performance with TMT's TMS and strategic flexibility as intervening variable.

To be specific, the conclusions of this study are as follows:

(1) The present study shows the mechanism where CEO's humble leadership behavior has a positive effect on start-up enterprise performance. From the empirical study, the regression coefficient of the CEO's humble leadership behavior on the start-up enterprise performance is significantly positive (0.472). The finding is in line with what Jiang et al. stated that leaders can promote knowledge sharing and exchange and cooperation among team members through acknowledging the merits and contributions of subordinates and learning modesty and then promote work motivation [31]. That is largely because that humble CEO can create a harmonious and relaxed environment and the humble CEO leads more followers to work hard to improve business performance by establishing a new shared vision. Additionally, the humble CEO creates an inclusive organizational learning climate within the organization, which is conducive to the improvement of start-up enterprise performance and provides the foundation for firm sustainable development.

(2) The TMT's transactive memory system plays a mediating role in the relationship between the CEO's humble leadership behavior and the start-up's performance. This conclusion confirms that humble leadership, as a "bottom-up" leadership style, conforms to employees' expectations of leaders in a global culture, and its characteristics will bring psychological security to the TMT members. Specifically, first, this sense of psychological security can promote the understanding and cognition of TMT's expertise in different fields, and thus further help the TMT to integrate knowledge and experience in multiple fields and make better strategic choices and organizational decisions, ultimately promoting the start-up's performance. Second, the psychological safety atmosphere transmitted by the CEO's humble leadership behavior to the TMT will also inspire the TMT members to challenge traditional concepts, invest more time and energy in allocating cognitive resources, and thus gain more through internal team communication and information sharing and avoid ignoring the market environment and relevant information from competitors to the greatest extent. Thirdly, this atmosphere is also an important prerequisite for effectively promoting the TMT to maintain effective teamwork. The high degree of collaboration among members of the TMT facilitates the efficient integration of resources, such as knowledge, skills, and experience, thereby enhancing the ability of the TMT to respond to the business environment and thus ultimately achieve an effective improvement in corporate performance. In short, CEO's humble leadership behavior improves the transactive memory system of the TMT by admitting their own shortcomings, affirming the value of employees, respecting each other, and trusting the subordinates. The TMT's transactive memory system can improve the knowledge exchange and combination of the enterprise by strengthening the complementarity and collaboration of expertise among members. This will significantly improve organizational performance. Additionally, workforce engagement is a central element of transforming a firm's sustainability mission, strategy, and values into measurable results. From the above discussion, the humble CEO can engage the TMT workforce in working together and transform the firm's sustainability mission into measurable results [88].

(3) This paper explores the moderating effect of strategic flexibility in the research model. Firstly, strategic flexibility positively moderates the relationship between CEO's humble leadership behavior 
and start-up enterprise performance. That is, the more flexible the corporate strategy, the stronger effect the CEO's humble leadership behavior has on the positive impact of start-up enterprise performance. This is because the start-up enterprise is limited in integrating and building internal and external resources when compared with mature large enterprises. Strategic flexibility enables the enterprises to better coordinate and allocate resources, improve resource utilization efficiency, reduce cross-border search costs, enhance corporate coordination capabilities, and promote flexibility and creativity in problem solving. Therefore, under the guidance of strategic flexibility, the start-up enterprise will be able to respond flexibly to complex external environments. It should be noted that high strategic flexibility may reduce the CEO's decision-making errors in leading the development of the company. Overall, the CEO can more effectively identify resources and opportunities that match his own capabilities, integrate redundant resources, reduce entrepreneurial costs, increase resource reuse, and improve business performance with higher strategic flexibility of the enterprise. Secondly, the regulatory role of strategic flexibility between CEO's humble leadership behavior and TMT's TMS has not been verified. The reason for this may be that strategic flexibility is a dynamic ability of an enterprise to respond to environmental changes in a timely and effective manner and a basic approach to the environment. It has a significant impact on corporate resources and competitive advantage, so the CEO's impact on the TMT's TMS is weak. Therefore, this hypothesis has not been verified.

\subsection{Theoretical Contribution}

The theoretical contributions of this research are as follows:

(1) This article expands upper echelons theory by comprehensively exploring the significant effect of CEO's humble leadership behavior on start-up firm performance. Previous research has focused on the impact of different leadership styles on team performance and neglected the importance of CEO humility on start-up performance. This research provides theoretical support for a more detailed explanation of the positive impact of CEO's humble leadership behavior on start-up performance. In addition, humble leadership is an independent charismatic leadership style. Our study offers a better understanding of the interplay of CEO leadership and TMT's transactive memory system and complements previously studied contingencies regarding leadership behavior or team knowledge integration in broader diversity literature.

(2) This study introduces the transactive memory system into the field of TMTs and explores the mediating role of the TMT's transactive memory system in the relationship between CEO's humble leadership behavior and entrepreneurial performance. Previous research on TMS has mainly focused on exploring the effects on general work teams [35,39], and few scholars have extended it to the field of TMTs to investigate its important influence on the TMT. Therefore, this study not only effectively expands the relevant literature of the TMS but also proves the applicability of the TMS in the TMT. Furthermore, it also enriches the theory of CEO leadership behavior and TMT operation from the perspective of joint effects, which makes up for the gap of existing research on the relationship between CEO and TMT's transactive memory system.

(3) This study reveals the mechanism of humble leadership behavior of CEOs affecting start-up firms and the boundary conditions created under this mechanism. As a result, this study responds to previous scholars' calls for strengthening the mechanism of start-up enterprise performance; the "theoretical layout" of influencing factors on start-up enterprise performance is thus further expanded. In this study, start-up enterprises with highly strategic flexibility are better at prodding CEOs to actively adopt a flexible business strategy, and encourage employees to actively adopt leadership roles themselves all in accordance with the needs of the organization promoting employee goals that are consistent with organizational goals, leading to the mutual development of employees and the organization. In a business environment with a high level of strategic flexibility, employee involvement receives more emphasis in current management practice, reflecting the idea that a CEO's humble leadership behavior is regarded as a socially dynamic process. In addition, the moderating effect of strategic flexibility is added to the effect of CEO's humble leadership behavior on start-up 
enterprise performance, which provides empirical support for the role boundaries of CEO leadership in organizational performance and further proves that the effect of CEO leadership behavior is closely related to the strategic flexibility of the enterprise.

\subsection{Practical Contributions}

This study provides some inspiration for corporate management practices:

(1) In this age of the knowledge economy, as a type of new independent leadership style, humble leadership was only recently proposed. Most previous theoretical research has only analyzed its positive impact on employees and teams' performance. Nowadays, the positive role of CEO's humble leadership behavior has been widely shown in management practice. CEO's humble leadership behavior has a significant effect on stimulating employee's intrinsic motivation and forming subordinates' followership and self-expansion with the enhancement of individual self-consciousness. Therefore, the Chinese start-up leaders should face up to the role of humble leadership in promoting employee creativity. Leaders should strive to abandon the previous "top-down" authoritative leadership style, and adopt more "bottom-up" humbly leadership styles, so as to better promote the improvement of employees' creativity and further improve the company's rapid response to the challenges of accelerating iteration in various fields in a rapid changing era. From the perspective of enterprise strategy, companies can train leaders at all levels within the enterprise according to the three dimensions of humble leadership so that they have a clear self-knowledge, knowing how to appreciate others, and these could be teachable so as to create a humble TMT. As a result, humility can be a leadership culture within the company. In daily management, the CEO should proactively acknowledge his own shortcomings and errors, encourage subordinates to actively speak, support innovative strategic decisions of the TMT, and create a harmonious and relaxed working atmosphere to promote communication and interaction between the TMT and grassroots employees, then improve corporate performance.

(2) Due to increasing demand for making full use of members' knowledge diversity to enhance organization performance has gained shared cognition among senior leadership in start-up enterprise. Research shows that the transactive memory system of the TMT can effectively improve organizational performance. Senior managers must be fully aware of the importance of building a transactive memory system for the TMT. Especially, start-ups are mostly small and medium-sized enterprises, and they face far more difficulties in development than large enterprises. It is particularly important to strengthen the construction of transactive memory systems of senior management teams for start-up firms. With today's development of business globalization, TMT should balance and integrate the knowledge coopetition regarding knowledge diversity level. As the top leader, the CEO should be more prone to encourage executive team members to upgrade their specialization skills and cognitive style by exploratory learning and to share new knowledge with other team members timely.

(3) CEOs and executives of enterprises should attach great importance to strategic flexibility for start-ups. The more turbulent the business environment, the stronger the positive effect of strategic flexibility on organizational performance. CEO and TMT members can make full use of strategic flexibility to integrate various resources and ultimately improve corporate performance. Moreover, managers should be aware that in a relatively stable technologically dynamic environment, maintaining high strategic flexibility may not bring significant improvement in enterprise performance. Therefore, in the practice of business management, the level of organizational strategic flexibility must be consistent with the dynamic environment of the technology, and the company's own situation must be taken into consideration, not blindly pursuing high strategic flexibility.

\subsection{Limitations and Future Research}

Despite its contribution, this research study suffers from several limitations as other empirical work in the social sciences. First, this study does not use a strict tracking paradigm to collect data, so it is difficult to make accurate causal inferences. Second, with regards to the effect of humble CEO leadership behavior on start-up corporation sustainability, this study mainly focuses on the theorical 
analysis due to the limitation of data. Future studies can use more objective methods and experimental approaches to collect relevant data to empirically explore the effect of humble leadership on corporation sustainability in depth. Moreover, the sample enterprises selected in this study are start-up enterprises, and large and medium-sized enterprises can be selected for future research. Second, this study considered only the positive role of CEO's humble leadership and not its negative effects in extreme cases. In the future, scholars may consider the negative effects of CEO's humble leadership behavior in an organization. For example, the weakness and humility of humble leaders may inhibit leadership effectiveness. Finally, the mediating variable selected in this study is the transactive memory system of the TMT. Future research can expend the study on the relationship between CEOs humble leadership behavior and start-up firm performance by selecting innovation capability, team's psychological safety atmosphere, and executive emotional intelligence as mediation variables. Besides, future research can also explore the moderate effects of other variables to further clarify the role boundaries of CEO's humble leadership.

Author Contributions: Q.R. and Y.X. conceived and designed the experiments; Q.R. and R.Z. designed the infrastructure of the research; Q.R., Y.X., and R.Z. analyzed the data; J.L. evaluated the results; Q.R. wrote the first drift of the manuscript; Y.X, R.Z., and J.L. provided comments and helped to revise it; Y.X. checked the language of the manuscript. All authors have read and agreed to the published version of the manuscript.

Funding: This research was financially supported by the National Natural Science Foundation project (71602002) and National Natural Science Foundation project (71972002) of China. Ministry of Education Humanities and Social Science Foundation youth project (16YJC630156). The National Social Science Foundation project (18BGL034)

Acknowledgments: We thank all the CEOs and TMT members who participated in our program and the alumni of MBA program to help us to collect data. We also thank all the reviewers to provide the useful and valuable comments.

Conflicts of Interest: The authors declare no conflict of interest.

\section{References}

1. Tseng, C.C. Connecting self-directed learning with entrepreneurial learning to entrepreneurial performance. Int. J. Entrep. Behav. Res. 2013, 19, 425-446. [CrossRef]

2. Makri, M.; Scandura, T.A. Exploring the effects of creative CEO leadership on innovation in high-technology firms. Leadersh. Q. 2010, 21, 75-88. [CrossRef]

3. Khan, W.A.; Vieito, J.P. Ceo gender and firm performance. J. Econ. Bus. 2013, 67, 55-66. [CrossRef]

4. Petrenko, O.V.; Aime, F.; Recendes, T.; Chandler, J.A. The case for humble expectations: CEO humility and market performance. Strateg. Manag. J. 2019, 40, 1938-1964. [CrossRef]

5. Throop, W.; Mayberry, M. Leadership for the Sustainability Transition. Bus. Soc. Rev. 2017, 122, $221-250$. [CrossRef]

6. Morris, J.A.; Brotheridge, C.M.; Urbanski, J.C. Bringing humility to leadership: Antecedents and consequences of leader humility. Hum. Relat. 2005, 58, 1323-1350. [CrossRef]

7. Hackett, R.D.; Wang, G. Virtues and leadership. Manag. Decis. 2012, 50, 868-899. [CrossRef]

8. Owens, B.P.; Johnson, M.D.; Mitchell, T.R. Expressed humility in organizations: Implications for performance, teams, and leadership. Organ. Sci. 2013, 24, 1517-1538. [CrossRef]

9. Ou, A.Y.; Waldman, D.A.; Peterson, S.J. Do Humble CEOs Matter? An Examination of CEO Humility and Firm Outcomes. J. Manag. 2018, 44, 1147-1173. [CrossRef]

10. Peterson, S.J.; Walumbwa, F.O.; Byron, K.; Myrowitz, J. CEO positive psychological traits, transformational leadership, and firm performance in high-technology start-up and established firms. J. Manag. 2009, 35, 348-368. [CrossRef]

11. Criscuolo, P.; Nicolaou, N.; Salter, A. The elixir (or burden) of youth? Exploring differences in innovation between start-ups and established firms. Res. Policy 2012, 41, 319-333. [CrossRef]

12. Coad, A.; Segarra, A.; Teruel, M. Innovation and firm growth: Does firm age play a role? Res. Policy 2016, 45, 387-400. [CrossRef]

13. Ketprapakorn, N.; Kantabutra, S. Culture development for sustainable SMEs: Toward a behavioral theory. Sustainability 2019, 11, 2629. [CrossRef] 
14. Katz, R.; Allen, T.J. Organizational Issues in the Introduction of New Technologies. In The Management of Productivity and Technology in Manufacturing; Springer: Boston, MA, USA, 1985; pp. 275-300.

15. Mackey, A. The effect of CEOs on firm performance. Strateg. Manag. J. 2008, 29, 1357-1367. [CrossRef]

16. Carmeli, A.; Schaubroeck, J.; Tishler, A. How CEO empowering leadership shapes top management team processes: Implications for firm performance. Leadersh. Q. 2011, 22, 399-411. [CrossRef]

17. Buyl, T.; Boone, C.; Hendriks, W.; Matthyssens, P. Top management team functional diversity and firm performance: The moderating role of CEO characteristics. J. Manag. Stud. 2011, 48, 151-177. [CrossRef]

18. Lin, H.-C.; Dang, T.T.H.; Liu, Y.-S. CEO transformational leadership and firm performance: A moderated mediation model of TMT trust climate and environmental dynamism. Asia Pac. J. Manag. 2016, 33, 981-1008. [CrossRef]

19. Bunderson, J.S.; Sutcliffe, K.M. Comparing alternative conceptualizations of functional diversity in management teams: Process and performance effects. Acad. Manag. J. 2002, 45, 875-893.

20. Boone, C.; Hendriks, W. Top management team diversity and firm performance: Moderators of functional-background and locus-of-control diversity. Manag. Sci. 2009, 55, 165-180. [CrossRef]

21. Ensley, M.D.; Pearce, C.L.; Hmieleski, K.M. The moderating effect of environmental dynamism on the relationship between entrepreneur leadership behavior and new venture performance. J. Bus. Ventur. 2006, 21, 243-263. [CrossRef]

22. Noruzy, A.; Dalfard, V.M.; Azhdari, B.; Nazari-Shirkouhi, S.; Rezazadeh, A. Relations between transformational leadership, organizational learning, knowledge management, organizational innovation, and organizational performance: An empirical investigation of manufacturing firms. Int. J. Adv. Manuf. Technol. 2013, 64, 1073-1085. [CrossRef]

23. Brandon, D.P.; Hollingshead, A.B. Transactive memory systems in organizations: Matching tasks, expertise, and people. Organ. Sci. 2004, 15, 633-644. [CrossRef]

24. Wegner, D.M. Transactive Memory: A Contemporary Analysis of the Group Mind. In Theories of Group Behavior; Springer: New York, NY, USA, 1987; pp. 185-208.

25. Ren, Y.; Carley, K.M.; Argote, L. The contingent effects of transactive memory: When is it more beneficial to know what others know? Manag. Sci. 2006, 52, 671-682. [CrossRef]

26. Lewis, K. Measuring transactive memory systems in the field: Scale development and validation. J. Appl. Psychol. 2003, 88, 587. [CrossRef]

27. Nadkarni, S.; Narayanan, V.K. Strategic schemas, strategic flexibility, and firm performance: The moderating role of industry clockspeed. Strateg. Manag. J. 2007, 28, 243-270. [CrossRef]

28. Zhang, M.J. Information systems, strategic flexibility and firm performance: An empirical investigation. J. Eng. Technol. Manag. 2005, 22, 163-184. [CrossRef]

29. Owens, B.P.; Hekman, D.R. Modeling how to grow: An inductive examination of humble leader behaviors, contingencies, and outcomes. Acad. Manag. J. 2012, 55, 787-818. [CrossRef]

30. Ou, A.Y.; Tsui, A.S.; Kinicki, A.J.; Waldman, D.A.; Xiao, Z.; Song, L.J. Humble Chief Executive Officers' Connections to Top Management Team Integration and Middle Managers' Responses. Adm. Sci. Q. 2014, 59, 34-72. [CrossRef]

31. Jiang, H.; Liu, W.; Jia, L. How humble leadership influences the innovation of technology standards: A moderated mediation model. Sustainability 2019, 11, 5448. [CrossRef]

32. Tracy, B. How the Best Leaders Lead: Proven Secrets to Getting the Most Out of Yourself and Others; Amacom: New York, NY, USA, 2010; ISBN 0814414354.

33. Nielsen, R.; Marrone, J.A.; Slay, H.S. A new look at humility: Exploring the humility concept and its role in socialized charismatic leadership. J. Leadersh. Organ. Stud. 2010, 17, 33-43. [CrossRef]

34. Chiu, C.Y.C.; Owens, B.P.; Tesluk, P.E. Initiating and utilizing shared leadership in teams: The role of leader humility, team proactive personality, and team performance capability. J. Appl. Psychol. 2016, 101, 1705-1720. [CrossRef] [PubMed]

35. Rego, A.; Owens, B.; Leal, S.; Melo, A.I.; Cunha, M.P.E.; Gonçalves, L.; Ribeiro, P. How leader humility helps teams to be humbler, psychologically stronger, and more effective: A moderated mediation model. Leadersh. Q. 2017, 28, 639-658. [CrossRef]

36. Zhang, H.; Ou, A.Y.; Tsui, A.S.; Wang, H. CEO humility, narcissism and firm innovation: A paradox perspective on CEO traits. Leadersh. Q. 2017, 28, 585-604. [CrossRef] 
37. Wegner, D.M.; Giuliano, T.; Hertel, P.T. Cognitive Interdependence in Close Relationships. In Compatible and Incompatible Relationships; Springer: New York, NY, USA, 1985; pp. 253-276.

38. Lewis, K.; Lange, D.; Gillis, L. Transactive memory systems, learning, and learning transfer. Organ. Sci. 2005, 16, 581-598. [CrossRef]

39. Heavey, C.; Simsek, Z. Distributed cognition in top management teams and organizational ambidexterity: The influence of transactive memory systems. J. Manag. 2017, 43, 919-945. [CrossRef]

40. Lewis, K. Knowledge and performance in knowledge-worker teams: A longitudinal study of transactive memory systems. Manag. Sci. 2004, 50, 1519-1533. [CrossRef]

41. Austin, J.R. Transactive Memory in Organizational Groups: The Effects of Content, Consensus, Specialization, and Accuracy on Group Performance. J. Appl. Psychol. 2003, 88, 866-878. [CrossRef]

42. Moreland, R.L.; Myaskovsky, L. Exploring the performance benefits of group training: Transactive memory or improved communication? Organ. Behav. Hum. Decis. Process. 2000, 82, 117-133. [CrossRef]

43. Lee, C.; Lee, K.; Pennings, J.M. Internal capabilities, external networks, and performance: A study on technology-based ventures. Strateg. Manag. J. 2001, 22, 615-640. [CrossRef]

44. Cyert, R.M.; March, J.G. A behavioral theory of the firm. Englewood Cliffs NJ 1963, 2, 169-187.

45. Naidoo, S.; Hewitt, M.; Bussin, M. A leadership model validation: Dimensions influential to innovation. $S$. Afr. J. Bus. Manag. 2019, 50. [CrossRef]

46. Leung, A.; Zhang, J.; Wong, P.K.; Foo, M. Der The use of networks in human resource acquisition for entrepreneurial firms: Multiple "fit" considerations. J. Bus. Ventur. 2006, 21, 664-686. [CrossRef]

47. Durst, S.; Edvardsson, I.R. Knowledge management in SMEs: A literature review. J. Knowl. Manag. 2012, 16, 879-903. [CrossRef]

48. González, T.F.; Guillén, M. The Ethical Dimension of Managerial Leadership Two Illustrative Case Studies in TQM. J. Bus. Ethics 2001, 34, 175-189.

49. Cameron, E.; Green, M. Making Sense of Change Management: A Complete Guide to the Models, Tools and Techniques of Organizational Change; Kogan Page Publishers: London, UK, 2019; ISBN 0749496983.

50. Lacy, P.; Arnott, J.; Lowitt, E. The challenge of integrating sustainability into talent and organization strategies: Investing in the knowledge, skills and attitudes to achieve high performance. Corp. Gov. 2009, 9, 484-494. [CrossRef]

51. Samul, J. Spiritual Leadership: Meaning in the Sustainable Workplace. Sustainability 2019, 12, 267. [CrossRef]

52. Heavey, C.; Simsek, Z. Transactive memory systems and firm performance: An upper echelons perspective. Organ. Sci. 2015, 26, 941-959. [CrossRef]

53. Wei, L.; Wu, L. What a diverse top management team means: Testing an integrated model. J. Manag. Stud. 2013, 50, 389-412. [CrossRef]

54. Boisot, M.H. Knowledge Assets: Securing Competitive Advantage in the Information Economy; OUP: Oxford, UK, 1998; ISBN 0191589349.

55. Connelly, C.E.; Zweig, D.; Webster, J.; Trougakos, J.P. Knowledge hiding in organizations. J. Organ. Behav. 2012, 33, 64-88. [CrossRef]

56. Ding, W.; Choi, E.; Aoyama, A. Relational study of wise (phronetic) leadership, knowledge management capability, and innovation performance. Asia Pac. Manag. Rev. 2019, 24, 310-317. [CrossRef]

57. Boonman, H.J.; Hagspiel, V.; Kort, P.M. Dedicated vs. product flexible production technology: Strategic capacity investment choice. Eur. J. Oper. Res. 2015, 244, 141-152. [CrossRef]

58. Akgun, A.E.; Byrne, J.C.; Keskin, H.; Lynn, G.S. Transactive memory system in new product development teams. IEEE Trans. Eng. Manag. 2006, 53, 95-111. [CrossRef]

59. Randall, K.R.; Resick, C.J.; DeChurch, L.A. Building team adaptive capacity: The roles of sensegiving and team composition. J. Appl. Psychol. 2011, 96, 525. [CrossRef] [PubMed]

60. Hecht, T.D.; Allen, N.J. Confronting failure: Antecedents and consequences of shared beliefs about failure in organizational work groups Learning from Failure in Organizations. J. Organ. Behav. 2009, 30, 839-862. [CrossRef]

61. Ren, Y.; Argote, L. Transactive memory systems 1985-2010: An integrative framework of key dimensions, antecedents, and consequences. Acad. Manag. Ann. 2011, 5, 189-229. [CrossRef]

62. Kanawattanachai, P.; Yoo, Y. The impact of knowledge coordination on virtual team performance over time. Q. Manag. Inf. Syst. 2007, 31, 783-808. [CrossRef] 
63. Hu, Y.; Zhao, X.; Chen, Y. The influence of managerial mindfulness on innovation: Evidence from China. Sustainability 2019, 11, 2914. [CrossRef]

64. Srivastava, A.; Bartol, K.M.; Locke, E.A. Empowering leadership in management teams: Effects on knowledge sharing, efficacy, and performance. Acad. Manag. J. 2006, 49, 1239-1251. [CrossRef]

65. Xue, Y.; Bradley, J.; Liang, H. Team climate, empowering leadership, and knowledge sharing. J. Knowl. Manag. 2011, 15, 299-312. [CrossRef]

66. Ashleigh, M.; Prichard, J. An integrative model of the role of trust in transactive memory development. Gr. Organ. Manag. 2012, 37, 5-35. [CrossRef]

67. Kantabutra, S. Achieving corporate sustainability: Toward a practical theory. Sustainability 2019, 11, 4155. [CrossRef]

68. Jackson, M.; Moreland, R.L. Transactive Memory in the Classroom. Small Gr. Res. 2009, 40, 508-534. [CrossRef]

69. Politis, J.D. The relationship of various leadership styles to knowledge management. Leadersh. Organ. Dev. J. 2001, 22, 354-364. [CrossRef]

70. Deci, E.L.; Ryan, R.M. The "what" and "why" of goal pursuits: Human needs and the self-determination of behavior. Psychol. Inq. 2000, 11, 227-268. [CrossRef]

71. Johnson, J.L.; Lee, R.P.W.; Saini, A.; Grohmann, B. Market-focused strategic flexibility: Conceptual advances and an integrative model. J. Acad. Mark. Sci. 2003, 31, 74-89. [CrossRef]

72. Wei, Z.; Yi, Y.; Guo, H. Organizational Learning Ambidexterity, Strategic Flexibility, and New Product Development. J. Prod. Innov. Manag. 2014, 31, 832-847. [CrossRef]

73. Najmaei, A.; Sadeghinejad, Z. How does knowledge management matter in enterprise strategic flexibility? Multiple case study approach based on SMEs in Malaysia. IBIMA Bus. Rev. 2009, 1, 32-54.

74. Kilduff, M.; Angelmar, R.; Mehra, A. Top Management-Team Diversity and Firm Performance: Examining the Role of Cognitions. Organ. Sci. 2000, 11, 21-34. [CrossRef]

75. Luger, M.I.; Koo, J. Defining and tracking business start-ups. Small Bus. Econ. 2005, 24, 17-28. [CrossRef]

76. Debrulle, J.; Maes, J.; Sels, L. Start-up absorptive capacity: Does the owner's human and social capital matter? Int. Small Bus. J. Res. Entrep. 2014, 32, 777-801. [CrossRef]

77. Brislin, R.W. The Wording and Translation of Research Instruments. In Cross-Cultural Research and Methodology Series, Field Methods in Cross-Cultural Research; Lonner, W.J., Berry, J.W., Eds.; Sage Publications: Thousand Oaks, CA, USA, 1986; Volume 8, pp. 137-164.

78. Young-Ybarra, C.; Wiersema, M. Strategic Flexibility in Information Technology Alliances: The Influence of Transaction Cost Economics and Social Exchange Theory. Organ. Sci. 1999, 10, 439-459. [CrossRef]

79. Li, Y.; Miao, X.; Zheng, D.; Tang, Y. Corporate public transparency on financial performance: The moderating role of political embeddedness. Sustainability 2019, 11, 5531. [CrossRef]

80. Thongsri, N.; Chang, A.K.H. Interactions among factors influencing product innovation and innovation behaviour: Market orientation, managerial ties, and government support. Sustainability 2019, 11, 2793. [CrossRef]

81. Fornell, C.; Larcker, D.F. Evaluating Structural Equation Models with Unobservable Variables and Measurement Error. J. Mark. Res. 1981, 18, 39. [CrossRef]

82. Faul, F.; Erdfelder, E.; Buchner, A.; Lang, A.-G. Statistical power analyses using G* Power 3.1: Tests for correlation and regression analyses. Behav. Res. Methods 2009, 41, 1149-1160. [CrossRef]

83. Tang, T.-W.; Zhang, P.; Lu, Y.; Wang, T.-C.; Tsai, C.-L. The effect of tourism core competence on entrepreneurial orientation and service innovation performance in tourism small and medium enterprises. Asia Pac. J. Tour. Res. 2020, 25, 89-100. [CrossRef]

84. Baron, R.M.; Kenny, D.A. The moderator-mediator variable distinction in social psychological research: Conceptual, strategic, and statistical considerations. J. Pers. Soc. Psychol. 1986, 51, 1173. [CrossRef]

85. Hayes, A.F. Beyond Baron and Kenny: Statistical mediation analysis in the new millennium. Commun. Monogr. 2009, 76, 408-420. [CrossRef]

86. Preacher, K.J.; Hayes, A.F. Asymptotic and resampling strategies for assessing and comparing indirect effects in multiple mediator models. Behav. Res. Methods 2008, 40, 879-891. [CrossRef] 
87. Van Velsor, E.; Hind, P.; Wilson, A.; Lenssen, G. Developing leaders for sustainable business. Corp. Gov. Int. J. Bus. Soc. 2009, 9, 7-20.

88. Galpin, T.; Whittington, J.L. Sustainability leadership: From strategy to results. J. Bus. Strateg. 2012, 33, 40-48. [CrossRef]

(c)

(C) 2020 by the authors. Licensee MDPI, Basel, Switzerland. This article is an open access article distributed under the terms and conditions of the Creative Commons Attribution (CC BY) license (http://creativecommons.org/licenses/by/4.0/). 